\author{
Dwi Sulisworo \\ Lecturer of Physics Teacher Training \\ Ahmad Dahlan University, Yogyakarta, Indonesia \\ dwi.sulisworol@uad.ac.id \\ Triwati Rahayu \\ Lecturer of Indonesia Language and Letters \\ Ahmad Dahlan University, Yogyakarta, Indonesia \\ triwatirahayu@ymail.com \\ Rifai Nur Akhsan \\ Lecturer of English Teacher Training \\ Ahmad Dahlan University, Yogyakarta, Indonesia \\ rifai_uad@yahoo.com
}

\title{
THE STUDENTS' ACADEMIC WRITING SKILL AFTER IMPLEMENTING BLENDED LEARNING USING FACEBOOK
}

\begin{abstract}
Almost all students use smartphone for their daily activities. Nowadays, the student's literacy on information technology is very good, but sometimes it has not been considered in school learning. One of the essential competencies of undergraduate school is academic writing skill. There is a gap between the student competencies and the learning strategy in certain learning subjects. The aim of this research is to examine the effectiveness of blended mobile learning activity using Facebook to improve student writing skill. This research used timed essay examination to measure the writing skill after one semester learning activity using this strategy and student satisfaction responses to learning. There were four aspects used as criteria of writing skill: ideas, organization, wording, and flavor. The results showed that this learning approach had shown good results in some aspects, particularly in improving the skill of shaping ideas and organizing the ideas into written form. The uses of various learning strategies that make students more active and centered on students tend to increase the ability of students to search for new ideas creatively. Among others, the positive aspect is the students have the knowledge and understanding of new concepts that can support the idea of writing in the aspect of idea and various choices of words.
\end{abstract}

Keywords: active learning; blended learning; education; Facebook; mobile technology; social media.

\section{INTRODUCTION}

Communication skill in written form is one of the essential competencies for students. This competence will also greatly support a person in his work field. Various attempts are made by higher education institutions in various countries in the world in order to prepare graduates with good skills. In general, to achieve this competency, higher education institutions will not always allocate it in the course of its own, but as one of the targeted learning achievement in certain subjects.

The same thing also applied in education in Indonesia. In the ministerial regulations, it is revealed that one competency of undergraduate level is the ability to write scientifically. In general, the Indonesian people tend to be more dominant in the oral culture, but they are weak in written culture. It makes most Indonesian students have low focus on writing skills. It continuously happens in higher school. The demands of writing competence are the basis of learning efforts to look for alternatives in improving writing skills.

On the other hand, the penetration of information technology, especially in social media in Indonesia is very high, especially in the use of Facebook. From the distribution of age, it appears that most Facebook users are school students. However, from the real activities undertaken, it is seen that their content writing activities are very low, still. It is possible that Facebook is not being used optimally as a medium of learning to support students learning 
activities. This situation opens an opportunity to use this social media for improving students' writing skill.

There are things to consider in the use of Facebook in learning. Currently, the learning on campus is still conducted face-to- face in the classroom by implementing cooperative learning strategies. New demands related to the competence of written communication have been the basis for changes in the organization of learning in the classroom. In the course "Introduction to Education" followed by students in first semester, they tend to make adjustment of learning in higher education. With the existing good quality of students' literacy on Information Technology (IT) especially in the use of Facebook, blended learning approach that combines cooperative learning in the classroom with activities and assignments targeting writing skill improvement can be a good alternative.

Studies in measuring the success of learning process indicate that the ability or skill in writing is increasingly important for education and for the future of the graduates themselves. So that methods to improve writing skills have become areas of study that continues to be developed, implemented and researched. The learning approach applied in this study employs learning process in the course "Introduction to Education" as a means to improve writing skills. Therefore, the objective of this research is to improve students' academic writing skills with blended learning utilizing Facebook.

\section{THE THEORETICAL BACKGROUNDS}

\subsection{Blended Learning}

Mobile learning is a part of the electronic learning or e -learning that provides wider opportunities in a mobile way and more capabilities for students learning. Thus $\mathrm{m}$-learning can be defined differently from e -learning related to the mobility of students as learners [1] [2]. This learning can be done anywhere as long as students benefit from mobile technology [3] [4]. The Perspective toward mobile learning can be grouped into four, namely: techno centric, focusing on e -learning, formal education tools, and student-centered learning [1][5][6][7]. Nowadays, the emphasis on school technology is used to ensure effective learning supported with new opportunities and to encourage better learning performance [2][4][8].

In the situation of current development of information and communication technology that has been dominated by tablets, smart phones and touch screen devices for a variety of interests, mobile learning becomes a new alternative for the improvement of student learning activities in schools. One approach that makes use of mobile learning along with the use of classroom learning is blended learning. This approach allows students to learn better [9] [10].

The definition of blended learning has evolved along with the development of information and communication technology [11] [12]. Basically, the definition of blended learning leads on how to maximize the use of face-to -face and online learning [9] [13]. The implications of blended learning implementation in some institutions are the needs to prepare a set of policies, planning, resources, and relevant supports [14]. Many studies stated that blended learning is regarded as useful, fun, supporting, flexible and motivating for students [9][13]. However, when blended learning is only regarded as an application integration system, then it is insufficient to create a successful learning environment [11]. Thus, it becomes necessary to have a lesson plan that is capable to balance the activities between learning face to-face in the classroom and online learning.

There is a variety of recent studies showing the effectiveness of blended learning to improve learning performance. The flexibility of opportunity existing in the blended learning can be used for the improvement of writing skills, which still become a problem of learning 
outcomes at higher education. In order to create a positive learning environment, teachers should encourage students to be more participating. In their learning activities, they must find a way that allows them to make more social interactions [13] [15].

\subsection{Writing Skill}

In the education system of many countries, the assessment of writing skills and general academic achievement through timed-essay examinations has become increasingly applied in many education subjects [16][17]. This is because this way has contributed to the scoring finalization and the course selection.

Writing skill is a special ability that allows writers to express their thoughts in the form of meaningful words and of a mental interaction through written messages [18][19]. Writing skills can help learners to improve their independence, fluency and creativity in writing. Mastery of these skills will make the students communicate better in various ways so that others can understand their ideas.

Writing is a process that is carried out over a certain period. In writing, the writer needs more time to do some internal process. The length of time used for writing will vary among the writers. Even, some writers take more time to think only about what to write before making the initial draft. Writing is producing a sequence of sentences arranged in a certain order and linked together in a certain way. These sentences will be linked to any other sentence structure to be a manuscript that has an integrated whole unity. A text may consist of one or more paragraphs. The paragraph is a short script about 150 to 200 words. It usually consists of a main sentence as the topic and is followed by a series of sentences that support the main sentence. Therefore writing becomes a very complex cognitive activity and at the sentence level, the writer should control the content, format, sentence structure, vocabulary, punctuation, and spelling [20].

Based on the theory above, it can be concluded that writing is a process that occurs over a period of time to generate a sequence of sentences arranged in a certain order and linked together in a certain way that is cohesive and coherent. In writing, there are several aspects that must be considered by the writer to obtain good writing that includes content, organization, word choice or vocabulary, language usage, and mechanics (spelling and punctuation).

The process approach, combined with coaching and scaffolding writing experience would yield positive results in the improvement of skills. Scaffolding in learning can be done by providing keywords that appear in writing, and conducting a group discussion on specific topics. Providing insight regarding the material of a course within a curriculum can be utilized to reinforce the written content. This is because writing to the content of the curriculum can be an effective strategy for improving writing skills. Writing according to the content of curriculum will enhance students' opportunities to write, so it would be useful to develop their ability. Therefore, designing learning strategies with writing activities that appropriate with the content of curriculum will improve students' writing skill because they have been familiar with the concept being studied and teaching strategies being applied.

At the end of a certain period, the students' writing skill can be observed using a writing task within a certain time. Accuracy and precision in the assessment of guided-writing shows its increasing usage. The learning of writing process is very important for the students because it will allow them to express their thoughts, knowledge, and feelings efficiently. Learning more on the process of writing will enable them to express their ideas better. There are several opinions about the factors applied to assess a writing assignment from the results of this writing model. The elements to assess writings include content or idea, form or organization, grammar, style, and mechanics. 


\subsection{Conceptual Framework}

One of the essential competencies of undergraduate school is academic writing skill [18][19]. There is a lack between the student competencies and the learning strategy at certain learning subject. This problem is also revealed by researchers and educators in many disciplines, for example in medicine [21], mathematics [22], nursing [23], language [24], computer science [25], and sciences [26][27]. They also used various strategies that make technology more challenging [19], collaborative [25], interactive [28], and improving attitude [22].

Beside using technology integration on learning, they also used various strategies to improve student writing skill for instance structured workshop [26], writing retreat [30], metacognitive writing [31], collaborative writing [25], rater negotiation [32], and intensive intervention [23]. The aim of this research is to examine the effectiveness of blended mobile learning activity using Facebook to improve student writing skill. This research used timed essay examination to measure the writing skill after one semester learning activity using this strategy and student satisfaction responses to learning. Based on studies of writing skill from experts [33][34][35][36][37], it can be concluded that there were four aspects used as criteria of writing skill: ideas, organization, wording, and flavor.

The conceptual framework of this research is shown by scheme 1 .

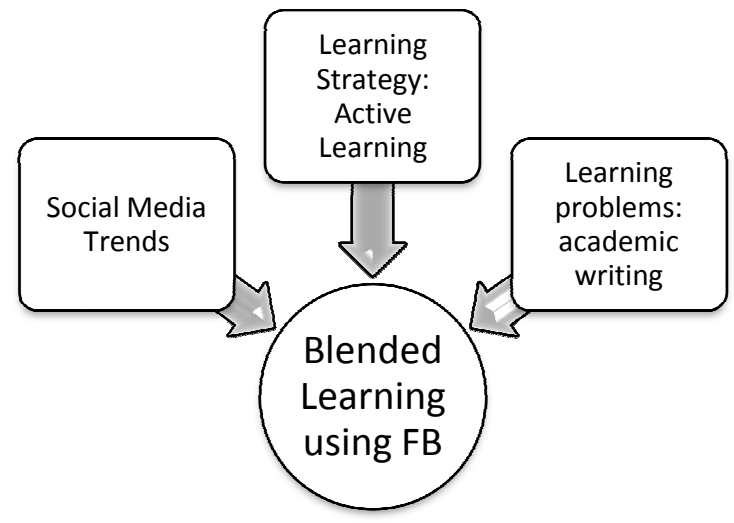

Scheme 1. The Conceptual Framework

\section{RESEARCH METHODS}

This research is an action research which was analyzed in descriptive quantitative. The research objects were students taking Introduction to Education subject for one semester from September 2015 to January 2016. The number of students was 61 students (13 male, 48 female). This study includes the preparation stage of understanding the capabilities of students, the implementation stage of blended learning, and the final stage, namely assessment or scoring of writing skill.

\subsection{Preparation Stage}

The initial stage is a stage to understand students' circumstances and to plan learning activities. The first meeting in the class was used to comprehend the characteristics of students related to their ability to express ideas, to search for new ideas, and to write the ideas. The results of the observation would identify the things that need to be improved in the learning process. From the discussions and observations at the first meeting, there were some 
learning problems encountered, namely: the ability of pouring ideas was still low, the ability to speak was still poor, and the students' ability to write down the ideas was inadequate.

\subsection{Implementation Stage}

This stage was carried out in 12 weekly meetings, each 100 minutes in duration. The meetings are not used only for delivering the material, but they also were used to allow students to gain optimal learning experience. The strategy used in the lecture was adjusted to the learning material. Some of the strategies were group discussion, working in pairs, and individual argumentation. Some techniques were also taught to lessen learning problems encountered at the beginning of learning such as mind mapping and brainstorming, so that the students could develop and find ideas. At each end of meeting, teacher gave students a topic and keywords to be dispensed into an article and to be uploaded on Facebook. In general, there were two models of learning activities, i.e. the model of learning in the classroom and online learning. The classroom learning activities include:

1. At the beginning of the semester, students are taught managing ideas using Mindmapping.

2. Every week while learning at the classroom, the lecturer gives certain learning topics and facilitates students using a variety of cooperative learning strategies.

3. Every week at the end of the lesson, the lecturer selects the specific topics for students to write about and post them on Facebook Group. The lecturer also provides 3 to 5 keywords that should be displaying in the online writing.

4. At the end of the semester, students are given the timed writing assignment related to the learning subject.

For the meantime, the online learning activities cover:

1. Students are paired two by two in a row. For example, student A to student B, B to $\mathrm{C}, \mathrm{C}$ to $\mathrm{D}$ and so forth. The second name assesses the first name's writing, based on certain criteria (described in the criteria).

2. Each student makes a writing with the certain criteria and posts them to the FB Group.

3. Pairs of students provide comments on posts related tasks with some criteria.

4. All students are encouraged to post comments on posted writing.

Meanwhile, the criteria used to assess the results of partner's postings are as follows:

1. The writing contains topics agreed in the classroom by entering the keyword given beforehand.

2. The text consists of 10 sentences at minimum.

3. The writing is made using proper Indonesian language

4. The writing does not contain plagiarism. If it does, it will be ignored, then.

5. All writings should be posted one week after task given

6. Assessment by the pair should be executed one week after posting date

7. The results of the assessment were written on post comments

\subsection{Scoring Stage}

The scoring stage takes place in the end of semester. All students should do a timedwriting task. The results would be scored using analytic scoring system in the scale 1-4 in which score $1=$ poor, $2=$ needs improvement, $3=$ good and $4=$ excellent. All students write an essay on education topic with certain criteria. Student can choose their own interest theme. They have 90 minutes to write best as many words as possible. The criteria for scoring the essay refers to the rubric. Rubric for scoring the writing product was shown on the table 1 below. 
Table 1.

Rubric for scoring the essay

\begin{tabular}{|c|c|c|}
\hline Factors & Rating Score & Remarks \\
\hline \multirow{4}{*}{ Ideas } & 4 (Excellent) & $\begin{array}{l}\text { Ideas are expressed in a clear and organized fashion. The } \\
\text { supporting examples are strong. }\end{array}$ \\
\hline & 3 (Good) & $\begin{array}{l}\text { Ideas are expressed in a clear manner, but the } \\
\text { organization could be better. Mix of strong and weak } \\
\text { supporting examples. }\end{array}$ \\
\hline & 2 (Needs Improvement) & $\begin{array}{l}\text { Ideas are not clear. More weak than strong supporting } \\
\text { examples. }\end{array}$ \\
\hline & 1 (Poor) & Extremely weak supporting examples, or none at all \\
\hline \multirow{4}{*}{ Organization } & 4 (Excellent) & $\begin{array}{l}\text { Sentences and paragraphs are complete. A wide variety } \\
\text { of conjunctions and transitions. }\end{array}$ \\
\hline & 3 (Good) & $\begin{array}{l}\text { All sentences are complete. Paragraphing is generally } \\
\text { done well. Some conjunctions and transitions are used } \\
\text { correctly. }\end{array}$ \\
\hline & 2 (Needs Improvement) & $\begin{array}{l}\text { Some sentences are okay but many are short. } \\
\text { Paragraphing is okay. Conjunctions/ transitions } \\
\text { attempted, but are incorrect. }\end{array}$ \\
\hline & 1 (Poor) & $\begin{array}{l}\text { Many sentence fragments or run-on sentences. } \\
\text { Paragraphs need work. Sentences are short. } \\
\text { Conjunctions and transitions are used incorrectly. }\end{array}$ \\
\hline \multirow{4}{*}{ Wording } & 4 (Excellent) & Excellent Hook/Thesis statement/ topic sentences \\
\hline & $3($ Good $)$ & Good Hook/Thesis statement/ topic sentences \\
\hline & 2 (Needs Improvement) & $\begin{array}{l}\text { Some good, some bad Hook/Thesis statement/ topic } \\
\text { sentences }\end{array}$ \\
\hline & 1 (Poor) & Terrible or didn't have. \\
\hline \multirow{4}{*}{ Flavor } & 4 (Excellent) & $\begin{array}{l}\text { It is easy to understand the main point on the first } \\
\text { reading. It "reads easily." }\end{array}$ \\
\hline & 3 (Good) & $\begin{array}{l}\text { The essay is easy to understand upon first reading, but } 1 \\
\text { or } 2 \text { areas could use some improvement. }\end{array}$ \\
\hline & 2 (Needs Improvement) & $\begin{array}{l}\text { The essay is not easily understood up first reading. } \\
\text { Second or third reading is required. }\end{array}$ \\
\hline & 1 (Poor) & $\begin{array}{l}\text { The essay is not able to be understood even upon } 3 \text { or } 4 \\
\text { readings. }\end{array}$ \\
\hline \multirow{4}{*}{ Mechanics } & 4 (Excellent) & 1-2 small errors. Good use of higher level vocab. \\
\hline & $3($ Good $)$ & 3-5 small errors. Some higher level vocab used. \\
\hline & 2 (Needs Improvement) & $\begin{array}{l}\text { 6-8 errors. Uses simple words correctly. No attempt to } \\
\text { use higher level vocab. }\end{array}$ \\
\hline & 1 (Poor) & $\begin{array}{l}\text { Writer makes so many errors that it is difficult to read. } \\
\text { No attempt at higher level vocab. Bad punctuation. }\end{array}$ \\
\hline
\end{tabular}

\section{THE RESULTS AND DISCUSSION}

\subsection{Classroom Learning}

In general, the classroom learning could run properly in accordance with the class schedule set by the management. The learning materials used were materials related to the Introduction to Education. Student's attendance was checked at every meeting. The students' attendance in every meeting is not always reaching $100 \%$. The average student's attendance rate was $95 \%$ for 12 meetings. The recapitulation of activity during class lessons was shown in table 2 below. 
Tabel 2.

Types of learning activities in the classroom

\begin{tabular}{|l|l|l|}
\hline No & \multicolumn{1}{|c|}{ Strategy } & \multicolumn{1}{c|}{ Meeting No...\# } \\
\hline 1 & Group discussion & $3,5,8,12$ \\
\hline 2 & Individual Presentation & $4,7,11$ \\
\hline 3 & Teacher presentation and class discussion & $1,2,10$ \\
\hline 4 & Group assignment & 6,9 \\
\hline
\end{tabular}

During the course, the students are allowed to use their gadgets to look for information related to the topic and materials studied at the time. At the end of each lecture, the lecturer will deliver writing topics and keywords that must appear in their writings. At the end of the course, 30 students were randomly drawn to fill the questionnaire related to the response toward the lecturer during interaction in the classroom learning. The results of this questionnaire can be seen in Table 3 below.

Tabel 3 .

Student's response to learning

\begin{tabular}{|c|l|c|c|c|c|}
\hline \multirow{2}{*}{ No } & \multicolumn{1}{|c|}{ Items } & \multicolumn{3}{c|}{ Student's Responses } \\
\cline { 3 - 5 } & & DS & D & A & SA \\
\hline 1 & $\begin{array}{l}\text { Teacher has a good understanding on the learning } \\
\text { material }\end{array}$ & 0 & 0 & 6 & 24 \\
\hline 2 & $\begin{array}{l}\text { Teacher gave many examples to improve student's } \\
\text { understanding }\end{array}$ & 0 & 0 & 9 & 21 \\
\hline 3 & Teacher explained the learning material clearly & 0 & 0 & 10 & 20 \\
\hline 4 & $\begin{array}{l}\text { Teacher gave a good response to any student's } \\
\text { questions }\end{array}$ & 0 & 0 & 6 & 24 \\
\hline 5 & $\begin{array}{l}\text { Teacher delivered the learning material in } \\
\text { structural way }\end{array}$ & 0 & 0 & 14 & 16 \\
\hline 6 & Teacher 's strategy improved student's motivation & 0 & 0 & 18 & 12 \\
\hline 7 & Teacher managed the classroom effectively & 0 & 0 & 17 & 13 \\
\hline 8 & Teacher used various references & 0 & 0 & 19 & 11 \\
\hline
\end{tabular}

\section{Remarks:}

SD: Strongly disagree

D: Disagree

A: Agree

SA: Strongly Agree

From table 3 we can see that all students tend to choose Agree or Strongly Agree to all of the items in question. It can be said that the learning goes well. From Table 3 above we can make a diagram as seen in figure 1 below.

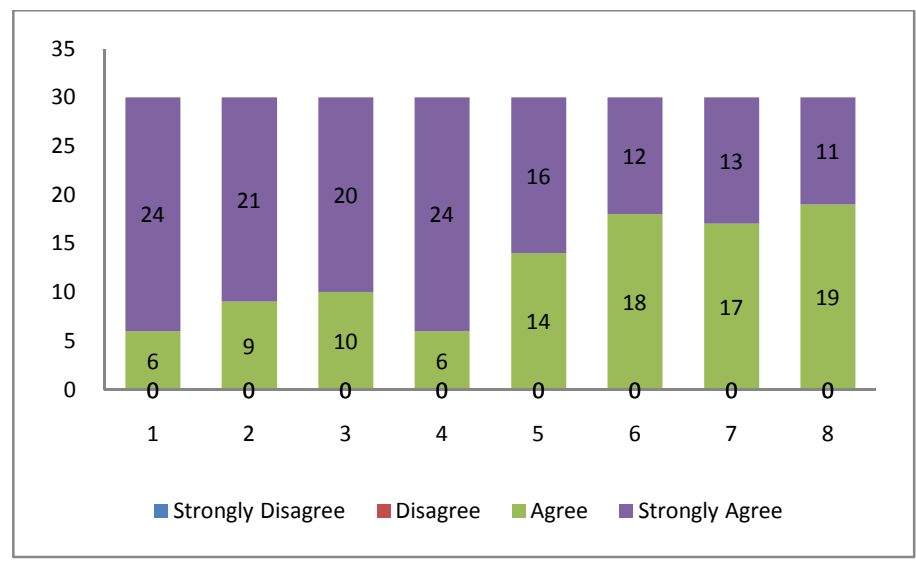

Figure 1. Response of learning by students 
From Figure 1, it appears that point statement on numbers 1 and 4 tends to be high because there are 24 students who stated Strongly Agree. It can be said that these aspects become the main factor in this type of learning, namely the statement: "Teacher has a good understanding on the learning material" and "Teacher gave a good response to any student's questions". The model of cooperative learning that promotes social skills does tend to encourage the interaction between students and professors. The score in the statement showed that cooperative learning has gone well. Meanwhile, as many as 11 students chose statement that has lowest points (Strongly Disagree), namely point number 8, stating that Teacher used various references. This is because at the time of delivery of materials and activities in the classroom, the teacher did not write the references primarily used in the classroom learning.

\subsection{Online Acitivity}

From figure 2 to 4 below is a sample screenshot of the online activities of students in the form of writing assignments and other tasks. Generally, during the implementation, there were 10 tasks performed by students that include 8 individual writing assignments and two group tasks in the discussion activity.

Figure 2 shows some picture of the classroom activities situation during the implementation of blended learning. Figure 3 shows one of the mind mapping produced by student group to improve their creativity to seek an idea. Figure 4 shows the last task posted by student related to the Bloom's Taxonomy as a part of learning materials. The other activities can be seen at the Facebook Group whose address is https://www.facebook.com/groups/pengpefis/.

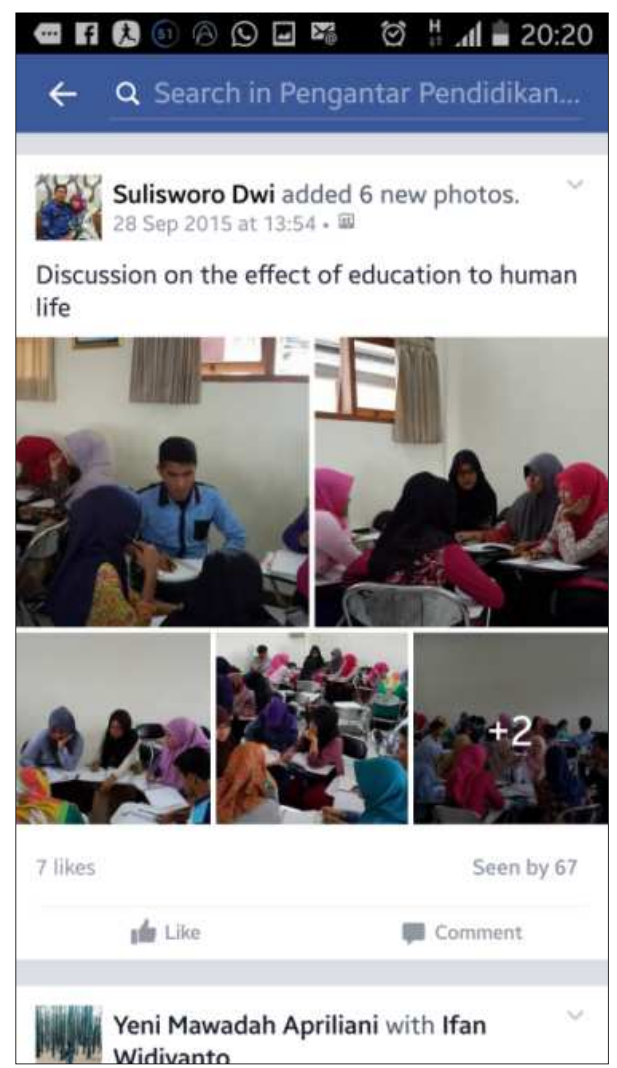

Figure 2. Classroom activities posted on FB

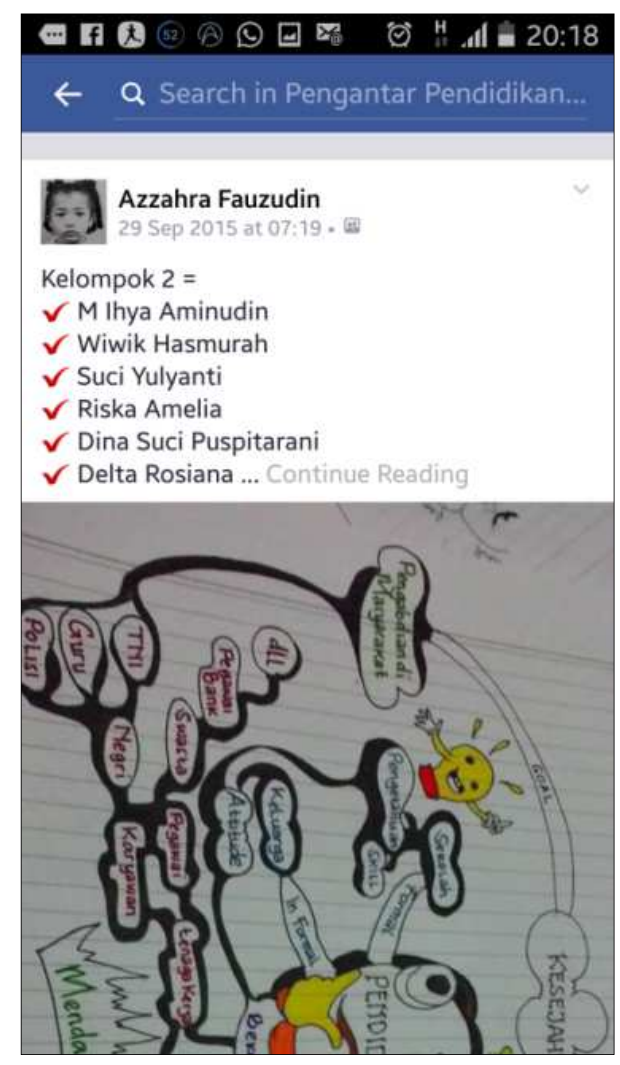

Figure 3. Example of screenshots of online activities 


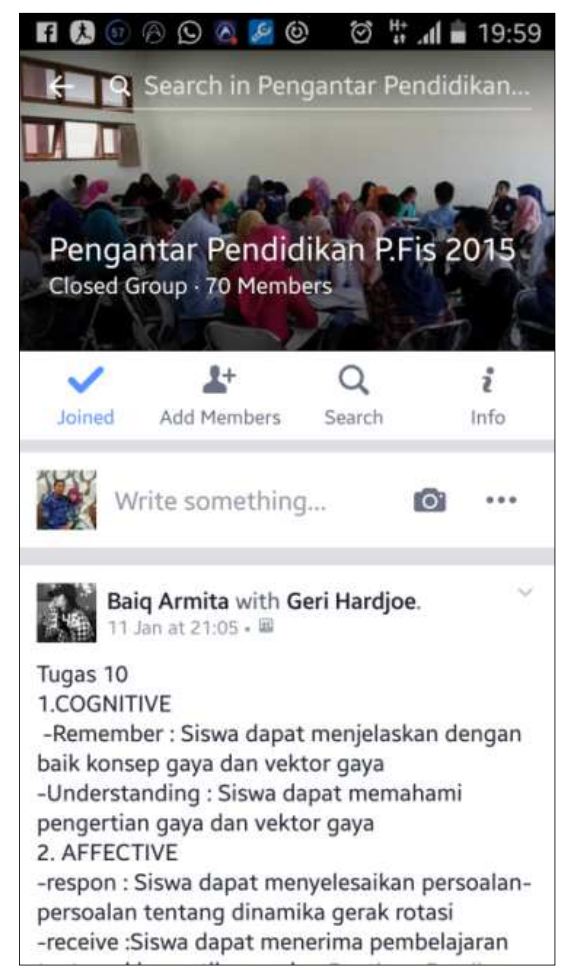

Figure 4. Screenshot of the last posting

By observing the findings during the learning activities described in the previous section, it can be concluded that the blended learning has been going well. It can be seen from the aspects (1) learning accomplishment, (2) the satisfaction level of student learning, and (3) the interaction of online learning conducted by teacher and students. The following information would discuss the improvement of students' writing quality after experiencing the blended learning.

\subsection{Writing Assignment Result}

To identify the ability of students to write their ideas, the lecturer gave a timed-writing assignment to students at the end of the course. As mentioned in the Method section, the essay criteria made is topics under education sector with certain criteria. Student can choose their own interest topic for their 90 minutes writing work. Results of the essay assessment based on the rubric are as follows (see table 4).

Table 4.

Rating Score of the writing assignment

\begin{tabular}{|l|r|r|r|r|}
\hline \multirow{2}{*}{ Factors } & \multicolumn{4}{|c|}{ Rating Score } \\
\cline { 2 - 5 } & \multicolumn{1}{|c|}{$\begin{array}{c}\text { Poor } \\
\%\end{array}$} & $\begin{array}{c}\text { Need } \\
\text { Improvement } \\
\text { \% }\end{array}$ & $\begin{array}{c}\text { Good } \\
\%\end{array}$ & $\begin{array}{c}\text { Excellent } \\
\%\end{array}$ \\
\hline \multirow{2}{*}{ Idea } & 0 & 6 & 26 & 29 \\
\hline \multirow{2}{*}{ Organization } & $0.0 \%$ & $9.8 \%$ & $42.6 \%$ & $47.5 \%$ \\
\hline \multirow{2}{*}{ Wording } & $0.0 \%$ & 8 & 31 & 32 \\
\hline Flavor & 0 & $13.1 \%$ & $50.8 \%$ & $36.1 \%$ \\
\cline { 2 - 5 } & $0.0 \%$ & 18 & 40 & $4.9 \%$ \\
\hline
\end{tabular}




\begin{tabular}{|l|r|r|r|r|}
\hline & $0.0 \%$ & $50.8 \%$ & $47.5 \%$ & $1.6 \%$ \\
\hline \multirow{2}{*}{ Mechanics } & 1 & 30 & 28 & 2 \\
\cline { 2 - 5 } & $1.6 \%$ & $49.2 \%$ & $45.9 \%$ & $3.3 \%$ \\
\hline
\end{tabular}

\subsubsection{Idea}

Aspect of the idea is the ability of students to express their ideas explicitly and completely with some examples or related opinions. Idea is the core of concept to be conveyed to the readers. From the above table we can create diagram of ideas aspect presented in figure 5 below.

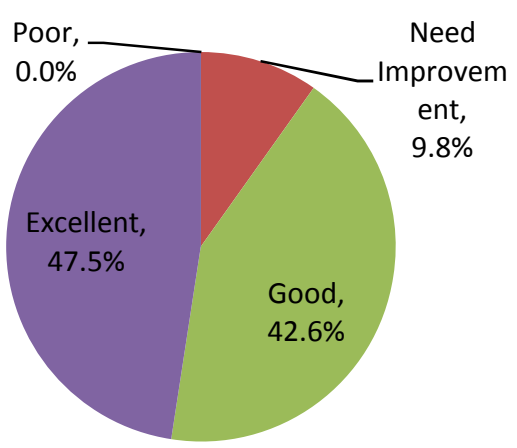

\section{Figure 5. Score on the aspect idea}

In general, we can see that there was no poor score in the aspect of idea, about $10 \%$ was in Need Improvement Category, and the rest were in Good and Excellent consecutively . Observations during the learning process that implement various cooperative strategies in the classroom and on Facebook show the growing tendency of students' ability improvement to search for new ideas. Some strategies that may foster these capabilities are mind mapping, brainstorming, group discussions, jigsaw learning method, the freedom to search for information using the mobile Internet during the lectures, the appreciation from the lecturer with a positive comment on any ideas of students, as well as displaying the students' results of online works during class meetings.

\subsubsection{Organization}

Aspect of the organization is the ability of students to manage writing that they created by using the sentences and paragraphs completely and interconnected to one another. The results on this aspect can be seen in Figure 6.

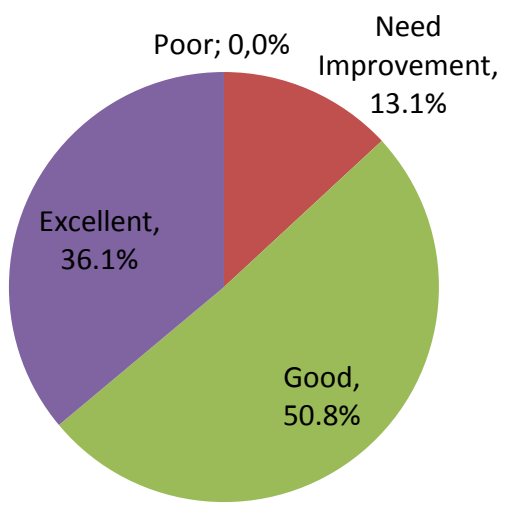

Figure 6. Score on Organization aspect 
In this aspect, $13 \%$ of students still need upgrading, and the remaining $87 \%$ had been already in a Good and Excellent category. From the essay made, in general students have no barriers to create sentences. It can be seen from the number of pages they can write. However, the ability to create interconnected sentences still needs to be improved with some students. The learning focus of improving learning to support this aspect is to teach mind mapping before writing. In this way, students can see the overall main idea of writing and other concepts that support the main idea. In the classroom meetings, this was done 3 times (task 3 , task 6 and task 9). The weak point is that the teacher did not give personal feedback to the students about this aspect. This is likely to be the factor that explains why score results on this aspect are not well improving with certain individuals.

\subsubsection{Wording}

Aspect of wording is the aspect of seeing the students' ability to choose words and use a variety of words so that their essay narration would be flowing and easy to read. This capability is basically influenced by the coverage of insight on the topic written by the students. Background knowledge will affect the students in choosing the words to make sentences explaining certain concepts. Score results for this ability can be seen in Figure 7 below.

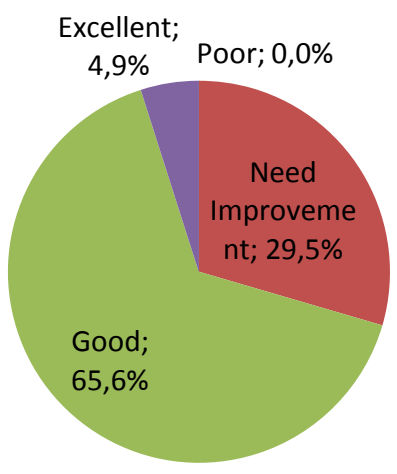

\section{Figure 7. Scores on wording aspect}

In the aspect of wording, $9.5 \%$ of students were in need improvement category. The remaining $90.5 \%$ were in good or excellent position. These results indicated that blended learning was applied well. Discussions carried out by the students, the tasks of reading through browsing in learning process, and the relevant topics presented by lecturer were several factors that increase the ability of students on the aspect of wording. These results also support the findings from other studies that the use of course material as a means of practicing writing will support the improvement of writing skills because the students would get new insight easily when the topic is relevant to the essay being written. These results were also relevant with the learning responses shown in Table 3 , especially at item number 2 (Teacher gave many examples to improve students' understanding) and number 3 (Teacher explained the learning material clearly).

\subsubsection{Flavor}

Aspect flavor of an article is an overview of how the readers feel easy to understand manuscripts related to the main topic that the writer wants to express. A complex concept but easily understood in a story will get a high score on this aspect. The ability to choose words that became the focus of the sentence, such as making active sentences, will increase the 
flavor in writing. The ability to estimate length of the sentence will also determine the flavor. Some students tend to make sentences too long with some of the main words. It made the sentence hard to understand. The results for this aspect were shown in Figure 8 below.

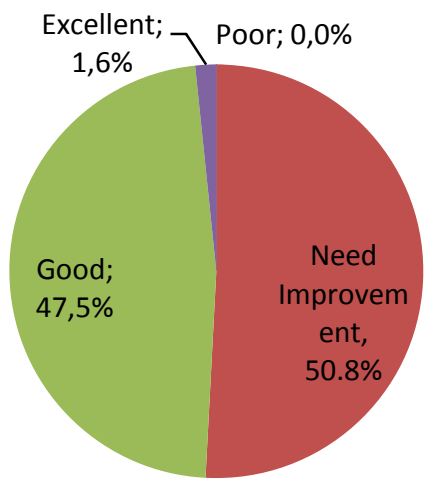

Figure 8. Score on flavor aspect

Based on Table 4, aspect of Flavor has the lowest score of all other aspects, in which $50.8 \%$ of students obtained score 2, meaning that they were in category of Need Improvement. It can be said that this aspect has the highest degree of difficulty compared to other aspects. Experiences in writing will determine the flavor of sentences. Actually, in each meeting the teacher has often reminded about how to make an effective sentence, but it brought relatively small effect on increasing the ability of the students. Extra hours of meetings for mentoring and providing individual feedback on this aspect possibly may enhance students' ability.

\subsubsection{Mechanics}

Aspect of Mechanics is very technical in writing. It relates to the accuracy of writing and the writing appearance in general. The aspect included in mechanics is the use of capital letters, punctuation, abbreviations and units of quantity. This aspect is basic ability that generally has been taught since elementary school. Discipline and accuracy become important factors in the aspect of mechanics. Scores of mechanics aspect were shown in Figure 9 below.

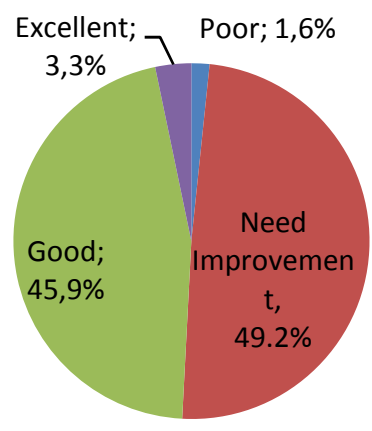

Figure 9. Scores on Mechanics aspect

Similar to the Flavor aspect, students are relatively less able to perform well in the aspect of mechanics. A total of $49.2 \%$ of the students were in a score of 2 or need improvement. Although no students received score 1 or poor, this condition should gain special attention in the learning process. Some errors frequently encountered in students' writings were (1) misunderstanding in the use of $-d i$ - or $-k e$ - as a preposition or as a prefix, 
(2) poor handwriting, so a bit hard to read, (3) the use of capital letters on the words in a sentence (4) Some students still use small letters at the beginning of the sentence. One of factors hampering students to improve in this aspect was the absence of the aspect as the focus of lesson. Consequently, students tend not to have sufficient learning experience on this aspect during the lectures. Students simply use their prior knowledge or skills and do nothing to improve their weakness in the aspect of mechanics. Extra hours of meetings for mentoring and providing individual feedback on this aspect may improve the ability of students.

\section{CONCLUSIONS AND PROSPECTS FOR FURTHER RESEARCH}

Communication skill in written form is one of important competencies to students. This capability will also greatly support a person in the world of work. Various attempts were made by higher education institutions in different countries to be able to equip the graduates with this capability. On the other hand, there is a great potential in the use of mobile technology in Indonesia, especially in the use of Facebook by young people. The importance of integration between improvement in writing skills and the use of Facebook in learning provides feasibility of conducting learning with blended learning approach. Some of qualitative results in this learning approach have shown good results in some aspects, particularly on improving the skill of shaping ideas and organizing the ideas into written form. The uses of various learning strategies that make students more active and centered on students tend to increase the ability of students to search for new ideas creatively. The use of a specific course material as a means to increase writing skill has shown positive and negative aspects. Among others, the positive aspect is that the students have the knowledge and understanding of new concepts that can support the idea of writing in the aspect of idea and various choices of words. Meanwhile, the negative aspect of this approach is the lack of increase in the student's skills in Flavor aspect and Mechanics aspect due to time constraints in learning. This is because there are also demands on the accomplishment of the learning materials in the lecture. In the end, it can be concluded that blended learning that combines classroom learning and interaction using Facebook is qualitatively suitable to improve students' writing skill.

\section{REFERENCES}

1. Tal, H. M., \& Gross, M. (2014). Teaching Sustainability via Smartphone-Enhanced Experiential Learning in a Botanical Garden. International Journal of Interactive Mobile Technology, 8(1), 10-15.

2. Thinley, P., Reye, J., \& Geva, S. (2014). Tablets (iPad) for M-Learning in the Context of Social Constructivism to Institute an Effective Learning Environment. International Journal of Interactive Mobile Technology; 8(1), 16-20.

3. Mohammad, H., Fayyoumi, A., \& AlShathry, O. (2015). Do We Have to Prohibit the Use of Mobile Phones in Classrooms? International Journal of Interactive Mobile Technology, 9(2), 54-57.

4. Ebrahim, H. S., Ezzadeen, K., \& A.K, A. (2015). Acquiring Knowledge through Mobile Applications. International Journal of Interactive Mobile Technology, 9(3), 71-74.

5. Chen, C.-H., Chen, S.-H., Hwang, G.-J., \& Yang, T.-C. (2010). Factors influencing teachers' adoption of a ubiquitous technology application in supporting teacher performance. International Journal of Mobile Learning and Organisation, 4(1), 39-54.

6. Crampton, A., Ragusa, A. T., \& Cavanagh, H. (2012). Cross-discipline investigation of the relationship between academic performance and online resource access by distance education students. Research in Learning Technology, 20, 1-13.

7. Kukulska-Hulme, A. (2007). Mobile Usability in Educational Contexts: What have we learnt? . International Review of Research in Open and Distance Learning, 8(2), 1-12. 
8. Babiker, M. E. (2015). For Effective Use of Multimedia in Education, Teachers Must Develop their Own Educational Multimedia Applications. TOJET: The Turkish Online Journal of Educational Technology, 14(4), 62-68.

9. Akkoyunlu, B., \& Soylu, M. Y. (2008). A Study of Student's Perceptions in a Blended Learning Environment Based on Different Learning Styles. Educational Technology \& Society, 11(1), 183-193.

10. Yen, J.-C., \& Lee, C.-Y. (2011). Exploring problem solving patterns and their impact on learning achievement in a blended learning environment. Computers \& Education, 56, 138-145.

11. Schober, A., \& Keller, L. (2012). Impact Factors for Learner Motivation in Blended Learning Environments. International Journal of Emerging Technology, 7(2: FNMA), 37-41.

12. Donnelly, R. (2010). Harmonizing Technology With Interaftion In Blended Problem-Based Learning. Computers and Education, 54(2), 350-359.

13. Delialioğlu, Ö. (2012). Student Engagement in Blended Learning Environments with Lecture-Based and Problem-Based Instructional Approaches. Educational Technology \& Society, 15(3), 310-322.

14. Poon, J. (2013). Blended Learning: An Institutional Approach for Enhancing Students' Learning Experiences. MERLOT Journal of Online Learning and Teaching, 9(2), 271-288.

15. Liu, S.-H. (2010). Factors related to pedagogical beliefs of teachers and technology integration. Computers \& Education, 56, 1012-1022.

16. Caudery, T. (1990). The validity of timed essay tests in the assessment of writing skills. ELT Journal, 44(2), 122-131.

17. Brown, G. T. (2010). The validity of examination essays in higher education: Issues and responses. Higher Education Quarterly, 64(3), 276-291.

18. Knoch, U., May, L., Macqueen, S., Pill, J., \& Storch, N. (2016). Transitioning from university to the workplace: Stakeholder perceptions of academic and professional writing demands. IELTS Research Reports Online Series, 37.

19. Jani, J. S., \& Mellinger, M. S. (2015). Beyond “Writing to Learn”: Factors Influencing Students' Writing Outcomes. Journal of Social Work Education,51(1), 136-152.

20. Flower, L., \& Hayes, J. R. (1981). A cognitive process theory of writing. College composition and communication, 32(4), 365-387.

21. Melvin, L., Connolly, K., Pitre, L., Dore, K. L., \& Wasi, P. (2015). Improving medical students' written communication skills: design and evaluation of an educational curriculum. Postgraduate medical journal, postgradmedj-2014.

22. Van Dyke, F., Malloy, E. J., \& Stallings, V. (2015). Conceptual writing in college-level mathematics courses and its impact on performance and attitude. International Journal of Mathematical Education in Science and Technology, 46(2), 223-233.

23. Miller, L. C., Russell, C. L., Cheng, A. L., \& Skarbek, A. J. (2015). Evaluating undergraduate nursing students' self-efficacy and competence in writing: Effects of a writing intensive intervention. Nurse education in practice, $15(3), 174-180$.

24. Barrot, J. S. (2016). Using Facebook-based e-portfolio in ESL writing classrooms: impact and challenges. Language, Culture and Curriculum, 1-16.

25. Adewoyin, O., Wu, K., \& Vassileva, J. (2015). Exploiting the Use of Wikis to Support Collaborative Writing: A Case Study of an Undergraduate Computer Science Class. In Collaboration and Technology (pp. 111-123). Springer International Publishing.

26. Verkade, H., \& Lim, S. H. (2016). Undergraduate Science Students' Attitudes Toward and Approaches to Scientific Reading and Writing. Journal of College Science Teaching, 45(4), 83.

27. Mercer-Mapstone, L. D., \& Matthews, K. E. (2015). Student perceptions of communication skills in undergraduate science at an Australian research-intensive university. Assessment \& Evaluation in Higher Education, 1-17.

28. Cordero, K., Nussbaum, M., Ibaseta, V., Otaíza, M. J., Gleisner, S., González, S., ... \& Chiuminatto, P. (2015). Read Create Share (RCS): A new digital tool for interactive reading and writing. Computers \& Education, 82, 486-496.

29. Dowd, J. E., Connolly, M. P., Thompson Jr, R. J., \& Reynolds, J. A. (2015). Improved reasoning in undergraduate writing through structured workshops. The Journal of Economic Education, 46(1), 14-27.

30. Garside, J., Bailey, R., Tyas, M., Ormrod, G., Stone, G., Topping, A., \& Gillibrand, W. P. (2015). Developing a culture of publication: a joint enterprise writing retreat. Journal of Applied Research in Higher Education, 7(2), 429-442.

31. Stewart, G., Seifert, T. A., \& Rolheiser, C. (2015). Anxiety and self-efficacy's relationship with undergraduate students' perceptions of the use of metacognitive writing strategies. The Canadian Journal for the Scholarship of Teaching and Learning, 6(1), 4.

32. Trace, J., Janssen, G., \& Meier, V. (2015). Measuring the impact of rater negotiation in writing performance assessment. Language Testing, 0265532215594830. 
33. Beck, S. W., Llosa, L., Black, K., \& Trzeszkowski-Giese, A. (2015). Beyond the Rubric. Journal of Adolescent \& Adult Literacy, 58(8), 670-681.

34. Greenberg, K. P. (2015). Rubric Use in Formative Assessment A Detailed Behavioral Rubric Helps Students Improve Their Scientific Writing Skills. Teaching of Psychology, 0098628315587618.

35. de Leeuw, J. (2016). Rubrics and Exemplars in Writing Assessment. In Leadership of Assessment, Inclusion, and Learning (pp. 89-110). Springer International Publishing.

36. McNaught, K., \& Shaw, G. (2016). Preparing undergraduate students to be successful writers: Exploring the Spelling, Grammar and Punctuation skills of students identified as potentially 'at risk'. Journal of Academic Language and Learning, 10(2), A11-A19.

37. Yi, J. (2009). Defining Writing Ability for Classroom Writing Assessment in High Schools. Pan-Pacific Association of Applied Linguistics, 13(1), 53-69 53.

\title{
НАВИЧКИ АКАДЕМІЧНОГО ПИСЬМА СТУДЕНТІВ ПІСЛЯ ВПРОВАДЖЕННЯ ЗМШШАНОГО НАВЧАННЯ ВИКОРИСТОВУЮЧИ ҒАСЕВООК
}

\author{
Дві Сулісворо \\ викладач, підготовка вчителів фізики \\ Університет Ахмад Дахлан, Джокьякарта, Індонезія \\ dwi.sulisworol@uad.ac.id

\section{Тріваті Рахав} \\ викладач Індонезійської мови і літератури \\ Університет Ахмад Дахлан, Джокьякарта, Індонезія \\ triwatirahayu@ymail.com \\ Ріфаї Нур Ахсан \\ викладач, підготовка вчителів англійської мови \\ Університет Ахмад Дахлан, Джокьякарта, Індонезія \\ rifai_uad@yahoo.com
}

\begin{abstract}
Анотація. Майже всі студенти використовують смартфон для своєї повсякденної діяльності і досить грамотно використовують інформаційні технології, що не завжди враховується під час їх навчання. Однією 3 важливих компетентностей студентів є навички академічного письма. Існує розрив між компетентностями студентів і стратегіями навчання 3 певних предметів. Метою даного дослідження $є$ вивчення ефективності змішаного мобільного навчання за допомогою Facebook, для того щоб поліпшити навички писемного мовлення студентів. У процесі дослідження було використано іспит з написання есе для того, щоб оцінити навички писемного мовлення, отримані після одного семестра навчання використовуючи цю технологію, а також дізнатися реакцію студентів на дану стратегію навчання. В ході дослідження були виділені чотири аспекти, що використовуються як критерії оцінювання навичок, отриманих з освоєння писемного мовлення: ідеї, організація, формулювання і почуття мови. Результати показали, що такий підхід до навчання $\epsilon$ позитивним в деяких аспектах, зокрема в підвищенні навичок для формування ідей i їх втілення в письмовій формі. Використання різних стратегій навчання, які роблять студентів більш активними і сфокусовані на студентах, як правило, підвищують їх здатність підходити до пошуку нових ідей творчо. Крім цього, позитивним аспектом є те, що студенти отримують знання і розуміння нових концепцій, що в свою чергу підтримує ідею для написання, а також розширює можливості різних варіантів вибору слів.
\end{abstract}

Ключові слова: активне навчання; змішане навчання; освіта; Facebook; мобільні технології; соціальні медіа. 


\title{
НАВЫКИ АКАДЕМИЧЕСКОЙ ПИСЬМЕННОЙ РЕЧИ СТУДЕНТОВ ПОСЛЕ ВНЕДРЕНИЯ СМЕШАННОГО ОБУЧЕНИЯ ИСПОЛЬЗУЯ ҒАСЕВООК
}

\author{
Дви Сулисворо \\ преподаватель по подготовке учителей физики \\ Университет Ахмад Дахлан, Джокьякарта, Индонезия \\ dwi.sulisworol@uad.ac.id \\ Тривати Рахаю \\ преподаватель Индонезийского языка и литературы \\ Университет Ахмад Дахлан, Джокьякарта, Индонезия \\ triwatirahayu@ymail.com \\ Рифаи Нур Ахсан \\ преподаватель по подготовке учителей английского языка \\ Университет Ахмад Дахлан, Джокьякарта, Индонезия \\ rifai_uad@yahoo.com
}

\begin{abstract}
Аннотация. Почти все студенты используют смартфон для своей повседневной деятельности и достаточно грамотно используют информационные технологии, что не всегда учитывается во время их обучения. Одной из важных компетентностей студентов являются навыки академической письменной речи. Существует разрыв между компетентностями студентов и стратегиями обучения определенных предметов. Целью данного исследования является изучение эффективности смешанного мобильного обучения с помощью Facebook, для того чтобы улучшить навыки письменной речи студентов. В процессе исследования был использован экзамен по написанию эссе для того, чтобы оценить навыки письменной речи, полученные после одного семестра обучения используя эту технологию, а также узнать реакцию студентов на данную стратегию обучения. В ходе исследования были выделены четыре аспекта, используемых в качестве критериев оценивания навыков, полученных по освоению письменной речи: идеи, организация, формулировки и чувство речи. Результаты показали, что такой подход к обучению является положительным в некоторых аспектах, в частности, в повышении навыков для формирования идей и их воплощению в письменной форме. Использование различных стратегий обучения, которые делают студентов более активными и сфокусированы на студентах, как правило, повышают их способность подходить к поиску новых идей творчески. Кроме этого, положительным аспектом является то, что студенты получают знание и понимание новых концепций, что в свою очередь поддерживает идею написания, а также расширяет возможности различных вариантов выбора слов.
\end{abstract}

Ключевые слова: активное обучение; смешанное обучение; образование; Facebook; мобильные технологии; социальные медиа.

Conflict of interest. The authors have declared no conflict of interest.

\section{(c) BY-NC-SA}

This work is licensed under Creative Commons Attribution-NonCommercial-ShareAlike 4.0 International License. 